\title{
Relationships of Chlorophyll and Enzyme Gradients to Sucrose Content of Sugarcane Leaves'
}

\author{
Alex G. Alexander and Ashok Kumar
}

\section{INTRODUCTION}

The products of ${ }^{14} \mathrm{CO}_{2}$ assimilation in sugarcane and the influence of physiological factors on their movement have been studied extensively since the mid-1960's by workers in Hawaii and Australia [reviewed by Alexander (6), chapters 3, 6, 7 and 8]. Sucrose, the primary end product, is also the principal transient form and remains intact during translocation $(22,15)$. This movement takes place both day and night $(16)$. Within the leaf, sucrose flow is invariably basipetal, moving from apex to base regardless of the blade orientation $(16,18,21)$.

The mechanism of sugar movement and its regulation in can leaves remains obscure. Some authors contend that the evacuation of photosynthetic end products from leaves to more permanent storage organs is necessary to prevent a repression of further $\mathrm{CO}_{2}$ assimilation $(16,9,17)$. Hartt $(20,16)$ found that red light is needed for maximum transport. but in such low intensities that neither photosynthesis nor respiration appeared to supply the requisite energy. A theory was proposed in which phytochrome exerts a regulatory effect on sugar translocation.

In the studies herein reported the distribution of $\beta$-amylase and ATPase within the leaf, among leaf ranks, and at different hours of the day were suggestive of enzymic contributions toward sucrose mobility. It is believed that by hydrolysis of immobile photosynthate and production of ATP, these systems play important roles in governing the basipetal flow of sucrose.

\section{MATERIALS AND METHODS}

Adult plants (cv M. 336) propagated in the humid Río Piedras region with standard fertilization were sampled at 0600,0800 or 1330 hours, depending on the experiment performed. Diurnal sampling times corresponded to low endogenous sucrose, low sucrose with active photosynthesis, and high sucrose with active photosynthesis, respectively. Tops were removed

1 Manuscript submitted to the Editorial Board March 7, 1974.

2 Plant Physiologist, Agricultural Experiment Station, University of Puerto Rico, Mayagüez Campus, Río Piedras, P.R. and Sugarcane Physiologist, Sugarcane Research Institute, C-220E Sector C, Mahanagar, Lucknow, India 226006, respectively. 
at the joint below leaf rank +7 and placed immediately in water. ${ }^{3}$ Within 2 hours they were transferred to the laboratory where the lower ends were again severed under water. Light intensity of the laboratory was approximately 2500 foot-candles and temperature varied from $20^{\circ}$ to $22^{\circ} \mathrm{C}$.

From the immersed cane tops, leaf samples were drawn from ranks -2 , $-1,0,+1,+2,+3,+5,+6$ and +7 . During a comparative study of the different sampling tissues only leaves $+1,+3,+5,+6$ and +7 were analyzed. The standard leaf sample was a composite of four leaves of identical rank from four uniform plants.

Performing all dissections under water, the intact blade was divided into five consecutive parts with the fifth section constituting the leaf apex. Sections 1 to 4, numbering from the base upward, measured $30 \mathrm{~cm}$ each. Fifteen-cm portions of each section were retained for analysis and the remaining material was discarded. All blade samples were washed in distilled water to remove surface residues. They were blotted, cut into small pieces, immersed in $100 \mathrm{ml}$ of chilled distilled water, and homogenized with a Waring blender operating at full speed for 2 minutes. The slurry was expressed through four layers of cheesecloth to remove tissue debris and centrifuged for 15 minutes at $2,500 \mathrm{r} / \mathrm{min}$. A sample of the supernatant was withdrawn for chlorophyll (8) and sucrose (12) analyses.

Protein was precipitated from the supernatant with solid ammonium sulfate, and the 0 to 80 percent fraction was used for enzyme analyses following dialysis for 2 hours against two changes of distilled water. ATPase (1) and $\beta$-amylase (2) were assayed in accordance with methods described previously. Protein content of enzyme preparations was determined by the method of Sutherland, et al. (26). Enzyme levels were computed as activity units or as specific activity (activity units per milligram of protein).

\section{RESULTS}

\section{CHLOROPHYLL}

All leaf ranks revealed a positive chlorophyll gradient which increased from base to apex and achieved maximal levels in leaf +2 (table 1). Chlorophyll content generally decreased between 0600 and 0800 hours, reviving by 1330 hours (table 2 ).

\section{SUCROSE}

Sucrose levels were highest in the leaf base and declined between the base and apex of all leaf ranks (table 3). This is consistent with Hartt (16, $19,21,14)$ who found a negative acropetal gradient for ${ }^{14} \mathrm{C}$-labelled photo-

The leaf nomenclature employed here is that of Kuijper, as described by Van Dillewijn (27), in which the highest leaf bearing a visible dewlap is designated +1 . 
TaBLE 1.-Chlorophyll content of consecutive leaf segments, from base to apex, among divergent leaf ranks'

\begin{tabular}{rrrrrrr}
\hline \multirow{2}{*}{ Leaf rank } & \multicolumn{5}{c}{ Chlorophyll, mg $\times 104 \mathrm{mg}$ leaf tissue, at cm- } & \multirow{2}{*}{ Mean } \\
\cline { 2 - 5 } & $0-30$ & $30-60$ & $60-90$ & $90-120$ & Aper & \\
\hline-2 & 1.8 & 5.2 & 6.8 & 9.2 & 11.6 & 6.9 \\
-1 & 2.8 & 6.2 & 8.6 & 11.0 & 11.6 & 8.0 \\
0 & 4.0 & 8.0 & 10.0 & 11.6 & 11.0 & 8.9 \\
+1 & 4.0 & 6.2 & 8.6 & 10.4 & 13.2 & 8.5 \\
+2 & 6.8 & 10.0 & 11.0 & 12.0 & 11.6 & 10.3 \\
+3 & 4.0 & 7.4 & 8.6 & 8.0 & 13.2 & 8.2 \\
+5 & 4.6 & 7.4 & 8.6 & 10.4 & 13.2 & 8.8 \\
+6 & 5.2 & 6.8 & 8.0 & 9.2 & 12.0 & 8.2 \\
+7 & 3.4 & 6.8 & 7.4 & 8.0 & 12.6 & 7.6 \\
\hline Mean & 4.1 & 7.1 & 8.6 & 10.0 & 12.2 & \\
\hline
\end{tabular}

1 Midrib removed.

TABLE 2.-Chlorophyll content of consecutive leaf segments, from base to apex, among divergent leaf ranks at different hours of the day ${ }^{2}$

\begin{tabular}{rrrrrrrr}
\hline \multirow{2}{*}{ Leat } & Hour & \multicolumn{5}{c}{ Chlorophyll, mg $\times 104 / \mathrm{mg}$ tissue, at cm- } & \multirow{2}{*}{ Mean } \\
\cline { 3 - 6 }+1 & $0-30$ & $30-60$ & $60-90$ & $90-120$ & Apex & \\
\hline \multirow{2}{*}{+1} & 0600 & 2.2 & 5.2 & 8.6 & 11.0 & 14.4 & 8.3 \\
& 0800 & 1.8 & 3.4 & 6.0 & 6.8 & 7.4 & 5.1 \\
& 1330 & 1.8 & 4.0 & 11.0 & 9.8 & 11.0 & 7.5 \\
+3 & 0600 & 2.8 & 6.0 & 8.0 & 10.4 & 13.2 & 8.1 \\
& 0800 & 2.2 & 4.6 & 6.2 & 7.4 & 8.6 & 5.8 \\
& 1330 & 2.2 & 5.2 & 7.4 & 9.8 & 11.0 & 7.1 \\
+5 & 0600 & 2.2 & 6.2 & 9.2 & 11.0 & 12.0 & 8.1 \\
& 0800 & 3.4 & 4.6 & 6.8 & 8.6 & 8.6 & 6.4 \\
& 1330 & 3.4 & 6.0 & 7.4 & 9.8 & 11.6 & 7.6 \\
& & & & & & & \\
+6 & 0600 & 2.2 & 5.2 & 9.8 & 11.6 & 11.0 & 8.0 \\
& 0800 & 2.8 & 4.6 & 6.8 & 8.6 & 8.6 & 6.3 \\
& 1330 & 2.2 & 6.0 & 8.0 & 9.2 & 11.0 & 7.3 \\
& & & & & & & \\
+7 & 0600 & 2.2 & 6.2 & 8.6 & 11.0 & 11.6 & 7.9 \\
& 0800 & 2.2 & 4.6 & 6.2 & 6.8 & 7.4 & 5.4 \\
& 1330 & 1.8 & 5.2 & 6.8 & 9.8 & 9.8 & 6.7 \\
\hline
\end{tabular}

1 Midrib included. 
synthate in leaf blades. More than half of the sucrose was localized in the midrib. Sucrose content was highest at 1330 hours in all but the youngest leaf rank (table 4). Mid-day sucrose accumulations, which represent a lag between maximal rates of transport and synthesis, were noted as early as 1936 by Hartt (13). She did not perceive at that time a rate relationship of sugar production to transport nor the prominence of sucrose as the chief photosynthate and mobile carbohydrate of sugarcane.

\section{$\beta$-AMYLASE AND ATPASE}

Activity values for $\beta$-amylase (table 5) varied among leaf ranks and pronounced diurnal changes were also noted (table 6). An increasing ac-

TABLE 3.-Sucrose content of consecutive leaf segments, from base to apex, among divergent leaf ranks ${ }^{2}$

\begin{tabular}{rrrrrrr}
\hline \multirow{2}{*}{ Leaf rank } & \multicolumn{5}{c}{ Sucrose, $\mathrm{mg} / \mathrm{g}$ dry wt, at $\mathrm{cm}-$} & \multirow{2}{*}{ Mean } \\
\cline { 2 - 5 } & $0-30$ & $30-60$ & $60-90$ & $90-120$ & Apex & \\
\hline-2 & 12.4 & 7.5 & 6.0 & 6.0 & 6.0 & 7.6 \\
-1 & 10.3 & 11.4 & 8.0 & 7.0 & 6.6 & 8.7 \\
0 & 20.3 & 14.5 & 12.4 & 8.0 & 8.0 & 12.6 \\
+1 & 21.2 & 13.4 & 9.0 & 6.6 & 5.8 & 11.2 \\
+2 & 32.9 & 16.3 & 11.9 & 10.0 & 8.0 & 15.8 \\
+3 & 24.8 & 13.7 & 10.3 & 6.6 & 5.8 & 12.5 \\
+5 & 25.4 & 19.2 & 12.4 & 9.0 & 6.6 & 14.5 \\
+6 & 23.6 & 17.8 & 14.5 & 10.3 & 8.0 & 14.8 \\
+7 & 37.4 & 24.2 & 15.5 & 10.0 & 8.0 & 19.0 \\
\hline Mean & 23.1 & 15.3 & 11.1 & 8.2 & 6.9 & \\
\hline
\end{tabular}

1 Midrib included.

tivity gradient from apex to base was found in all leaf ranks from -2 to +3. ATPase values were highest in newly emerging leaves (table 7) while on the whole there was little difference within the blade, between ranks, or between harvest times for mature leaves (table 8).

\section{DISCUSSION}

During the 1960's Hartt and her colleagues greatly clarified the form of transient photosynthate, its pathways of flow, and conditions affecting its movement in the cane plant [(6), chapters 7 and 8]. However, neither the transport mechanism nor the considerable forces needed to move such large quantities of sucrose were adequately explained. Physiologists still have not reached a concensus on these questions in higher plants as a whole $(10,24,11)$, and the concept of pressure flow gradients proposed by Münch in 1930 is still viewed as a plausible, though incomplete, explanation (10). 
TABLE 4.-Sucrose content of consecutive leaf segments, from base to apex, among divergent leaf ranks at different hours of the day ${ }^{1}$

\begin{tabular}{|c|c|c|c|c|c|c|c|}
\hline \multirow{2}{*}{ Leaí } & \multirow{2}{*}{ Hour } & \multicolumn{5}{|c|}{ Sucrose, $\mathrm{mg} / \mathrm{g}$ dry wt, at $\mathrm{cm}$ - } & \multirow{2}{*}{ Mean } \\
\hline & & $0-30$ & $30-60$ & $60-90$ & $90-120$ & Apex & \\
\hline \multirow[t]{3}{*}{+1} & 0600 & 32.9 & 31.0 & 18.1 & 11.9 & 12.4 & 21.3 \\
\hline & 0800 & 21.2 & 13.4 & 0.9 & 6.6 & 5.8 & 11.2 \\
\hline & 1330 & 26.0 & 21.2 & 15.5 & 19.2 & 21.8 & 20.7 \\
\hline \multirow[t]{3}{*}{+3} & 0600 & 26.8 & 18.4 & 13.4 & 10.3 & 10.6 & 15.9 \\
\hline & 0800 & 24.8 & 13.7 & 10.3 & 6.6 & 5.8 & 12.2 \\
\hline & 1330 & 30.4 & 21.8 & 18.1 & 18.4 & 21.8 & 22.1 \\
\hline \multirow[t]{3}{*}{+5} & 0600 & 20.6 & 17.8 & 11.4 & 10.0 & 10.3 & 14.0 \\
\hline & 0800 & 25.4 & 19.2 & 12.4 & 9.0 & 6.6 & 14.5 \\
\hline & 1330 & 22.6 & 18.1 & 18.4 & 18.4 & 16.6 & 18.8 \\
\hline \multirow[t]{3}{*}{+6} & 0600 & 24.8 & 14.0 & 11.4 & 10.0 & 10.3 & 14.1 \\
\hline & 0800 & 23.6 & 17.8 & 14.5 & 10.3 & 8.0 & 14.8 \\
\hline & 1330 & 27.4 & 23.6 & 21.8 & 20.3 & 17.8 & 22.2 \\
\hline \multirow[t]{3}{*}{+7} & 0600 & 18.1 & 11.4 & 10.6 & 10.0 & 8.5 & 11.7 \\
\hline & 0800 & 37.4 & 24.2 & 15.5 & 10.0 & 8.0 & 19.0 \\
\hline & 1330 & 30.4 & 21.2 & 19.2 & 16.6 & 12.4 & 20.0 \\
\hline \multicolumn{2}{|c|}{ Mean } & 26.2 & 19.1 & 14.6 & 12.5 & 11.8 & \\
\hline
\end{tabular}

1 Midrib included.

TABLE 5.-B-amylase activily in consecutive leaf segments, from base to apex among divergent leaf ranks ${ }^{1}$

\begin{tabular}{|c|c|c|c|c|c|c|}
\hline \multirow{2}{*}{ Leaf rank } & \multicolumn{5}{|c|}{ Specific activity, at $\mathrm{cm}-$} & \multirow{2}{*}{ Mean } \\
\hline & $0-30$ & $30-60$ & $60-90$ & $90-120$ & Apex & \\
\hline-2 & 52.7 & 115.8 & 89.7 & 43.2 & 20.5 & 64.4 \\
\hline-1 & 60.3 & 69.4 & 65.2 & 51.2 & 27.1 & 54.6 \\
\hline $\mathbf{0}$ & 43.3 & 54.9 & 47.0 & 30.2 & 12.7 & 37.6 \\
\hline+1 & 44.4 & 41.8 & 30.0 & 25.6 & 20.2 & 32.4 \\
\hline+2 & 46.7 & 16.3 & 17.2 & 16.1 & 9.5 & 21.2 \\
\hline+3 & 40.5 & 33.3 & 21.5 & 16.6 & 17.4 & 25.9 \\
\hline+5 & 23.7 & 25.8 & 24.8 & 19.9 & 16.8 & 22.2 \\
\hline+6 & 25.6 & 24.6 & 25.4 & 23.7 & 16.6 & 23.2 \\
\hline+7 & 31.9 & 25.9 & 22.4 & 21.3 & 20.2 & 24.3 \\
\hline Mean & 41.0 & 45.3 & 38.1 & 27.5 & 17.9 & \\
\hline
\end{tabular}

1 Midrib included.

2 Activity units per milligram of protein. 
TABLE 6.-B-amylase activity in consecutive leaf segments, from base to apex, at different hours of the day 1

\begin{tabular}{|c|c|c|c|c|c|c|c|}
\hline \multirow{2}{*}{ Leaf } & \multirow{2}{*}{ Hour } & \multicolumn{5}{|c|}{ Specific activity, 2 at $\mathrm{cm}-$} & \multirow{2}{*}{ Mean } \\
\hline & & $0-30$ & $30-60$ & $60-90$ & $90-120$ & Apex & \\
\hline \multirow[t]{3}{*}{+1} & 0600 & 35.6 & 32.6 & 20.2 & 15.6 & 7.2 & 22.2 \\
\hline & 0800 & 84.4 & 41.8 & 30.0 & 25.6 & 20.2 & 40.4 \\
\hline & 1330 & 32.8 & 33.0 & 23.5 & 14.7 & 13.5 & 23.5 \\
\hline \multirow{3}{*}{+3} & 0600 & 34.2 & 21.8 & 13.0 & 7.1 & 8.8 & 17.0 \\
\hline & 0800 & 40.5 & 33.3 & 21.5 & 16.6 & 17.4 & 25.9 \\
\hline & 1330 & 19.7 & 21.0 & 15.0 & 10.9 & 7.7 & 14.9 \\
\hline \multirow[t]{3}{*}{+5} & 0600 & 17.2 & 18.6 & 6.1 & 9.5 & 7.3 & 11.7 \\
\hline & 0800 & 23.7 & 25.8 & 24.8 & 19.9 & 16.8 & 22.2 \\
\hline & 1330 & 12.3 & 14.9 & $14: 3$ & 7.2 & 6.3 & 11.0 \\
\hline \multirow[t]{3}{*}{+6} & 0600 & 17.6 & 17.5 & 13.4 & 11.2 & 9.3 & 13.8 \\
\hline & 0800 & 25.6 & 24.6 & 25.4 & 23.7 & 16.6 & 23.2 \\
\hline & 1330 & 12.8 & 10.1 & 10.4 & 8.2 & 6.9 & 9.7 \\
\hline \multirow[t]{3}{*}{+7} & 0600 & 20.8 & 18.0 & 14.8 & 10.9 & 8.8 & 14.7 \\
\hline & 0800 & 31.9 & 25.9 & 22.4 & 21.3 & 20.2 & 24.3 \\
\hline & 1330 & 16.1 & 14.1 & 11.8 & 8.6 & 7.6 & 11.6 \\
\hline \multicolumn{2}{|c|}{ Mean } & 28.3 & 23.5 & 17.8 & 14.1 & 11.6 & \\
\hline
\end{tabular}

1 Midrib included.

2 Activity units per milligram of protein.

TABLE 7.-ATPase activity in consecutive leaf segments, from base to apex, among divergent leaf ranks ${ }^{1}$

\begin{tabular}{|c|c|c|c|c|c|c|}
\hline \multirow{2}{*}{ Leaf rank } & \multicolumn{5}{|c|}{ Specific activity, at $\mathrm{cm}-$} & \multirow{2}{*}{ Mean } \\
\hline & $0-30$ & $30-60$ & $60-90$ & $90-120$ & Apex & \\
\hline-2 & 50.4 & 134.0 & 77.6 & 55.3 & 38.4 & 71.1 \\
\hline-1 & 49.7 & 54.3 & 73.3 & 54.4 & 38.4 & 54.0 \\
\hline 0 & 30.3 & 41.4 & 36.4 & 40.8 & 34.2 & 36.6 \\
\hline+1 & 28.9 & 30.1 & 39.7 & 38.6 & 32.3 & 33.9 \\
\hline+2 & 16.1 & 16.2 & 19.8 & 24.3 & 23.5 & 20.0 \\
\hline+3 & 18.8 & 20.2 & 27.5 & 32.7 & 27.7 & 25.4 \\
\hline+5 & 14.9 & 19.8 & 20.0 & 20.8 & 27.1 & 20.5 \\
\hline+6 & 15.5 & 15.9 & 22.9 & 23.3 & 27.2 & 21.0 \\
\hline+7 & 15.9 & 18.1 & 20.8 & 19.6 & 23.4 & 20.0 \\
\hline Mean & 26.7 & 38.9 & 37.6 & 34.4 & 30.2 & \\
\hline
\end{tabular}

1 Midrib included.

2 Activity units per milligram of protein. 

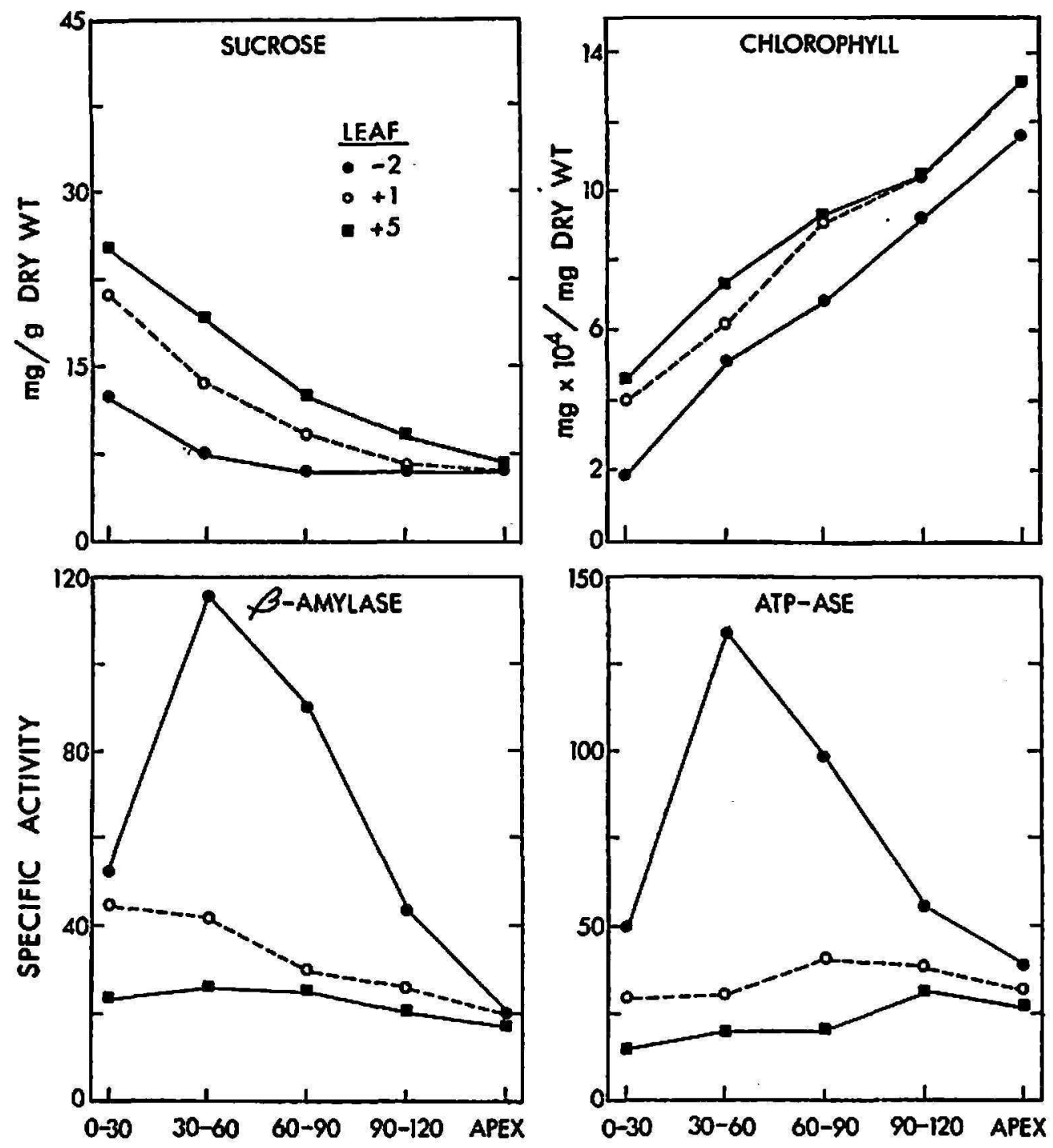

SEGMENT OF LEAF, $\mathrm{cm}$

Fra. 1.-Distribution of sucrose, chlorophyll, $\beta$-amylase, and ATPase in consecutive leaf segments, from base to apex, among divergent leaf ranks.

The hypothesis motivating our present experiments held that a relationship exists between the distribution of sucrose in sugarcane leaves and the polyglucoside- and ATP-hydrolyzing enzymes found in abundance in the same tissues. Hence it was thought that $\beta$-amylase and ATPase should reveal distribution trends commensurate with those of sucrose. Moreover, diurnal sucrose fluctuations might also be reflected in enzymic changes. Evidence herein reported strongly favors the hypothetical sugar-enzyme relationship.

Important data trends include the following: (a) A generally inverse relationship between sucrose and chlorophyll contents which persisted among divergent leaf ranks (fig. 1) and hour of the day (fig. 2); (b) a high 

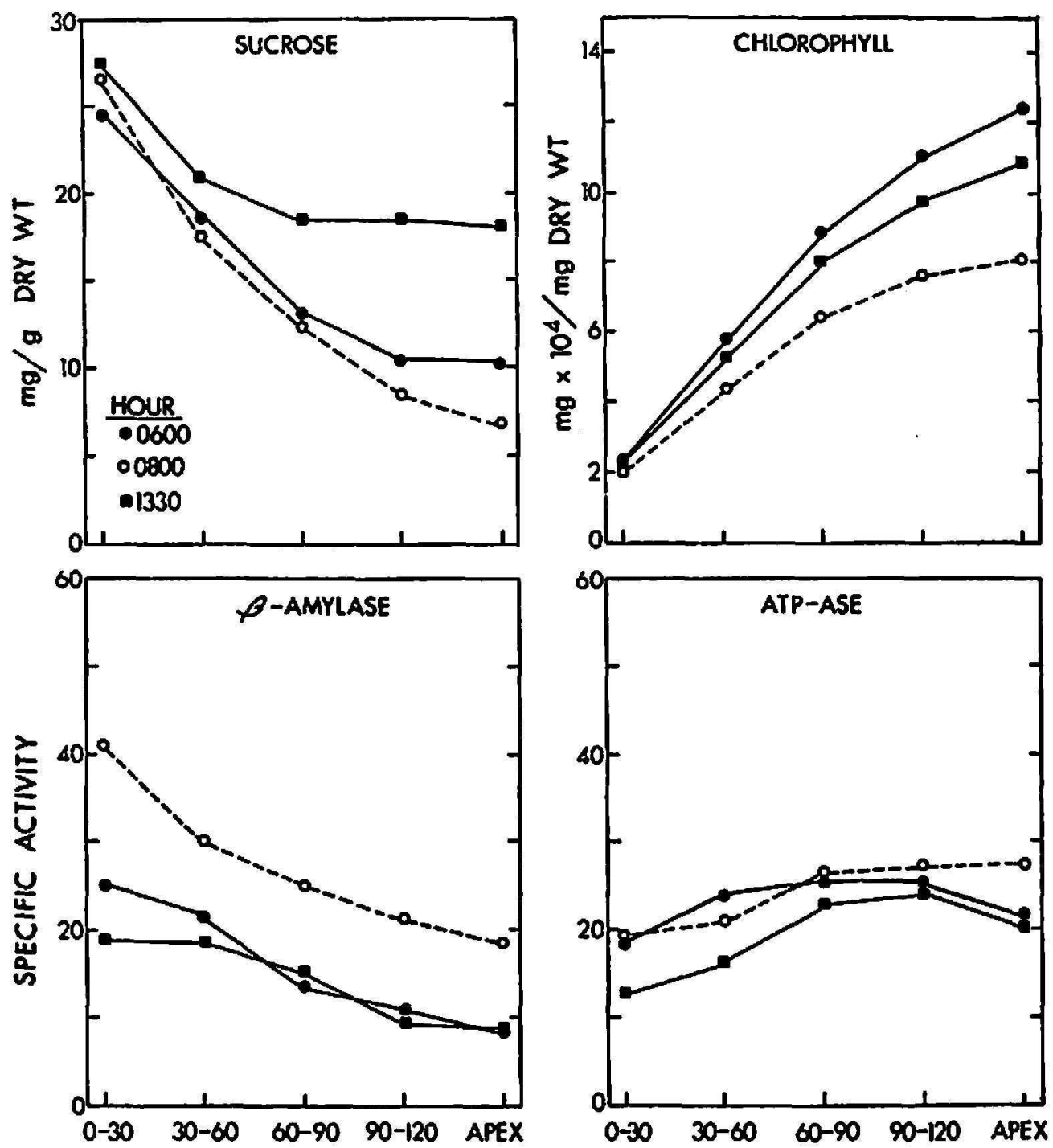

SEGMENT OF LEAF, $\mathrm{cm}$

Fra. 2.-Distribution of sucrose, chlorophyll, $\beta$-amylase, and ATPase in consecutive leaf segments, from base to apex, at different hours of the day. Values shown are the means for leaf ranks $+1,+3,+5,+6$ and +7 .

sensitivity of both $\beta$-amylase and ATPase to leaf rank and to their position within the leaf blade (fig. 1); (c) a consistency of ATPase level within the leaf blade and between ranks of mature leaves; and (d), a persistent increase of $\beta$-amylase activity between 0600 and 0800 hours, which related inversely to both sucrose and chlorophyll in the leaf segments most exposed to light (fig. 2).

With the photosynthetic unit situated in the chloroplast, and sucrose being the principal photosynthate of sugarcane $(22,15)$, a positive quantitative relationship should exist between the two factors under conditions wherein the synthesizing tissue is also utilized for sugar storage. To a degree 
this was true of the leaf-rank and hour-of-day data shown in figures 1 and 2 , that is, to the extent that the lowest sucrose values coincide with the lowest chlorophyll values. However, a generally inverse relationship appears when discrete slopes for sucrose and chlorophyll are interposed by base-toapex gradients. This is not interpreted as a production-storage phenomenon, but as a relatively greater capacity to remove sucrose from tissues bearing more chlorophyll. In a source-to-sink continuum this is more than a casual expediency owing to the sensitivity of photosynthesis to repression by its own products $(9,17)$. Of further interest was a severe loss of chlorophyll between 0600 and 0800 hours in those portions of the leaf most exposed to light (fig. 2). Light intensity per se does not appear to be the causal factor since chlorophyll levels were largely recovered under mid-day illumination.

The exceptionally high $\beta$-amylase and ATPase levels found in the lower half of leaf -2 are consistent with the operation of these systems in expediting sugar movement, the same tissue in fact bearing relatively little sucrose (fig. 1). Diurnal values for mature leaves $(+1$ to +7$)$ show a pragmatic increase of $\beta$-amylase between 0600 and 0800 hours (fig. 2). This corresponds in time to the lowest sucrose and chlorophyll values. However, the inverse acropetal slopes for $\beta$-amylase and chlorophyll suggest that the enzyme's site is external to the chloroplast and its behavior is not linked to light-receptive pigments. Presumably, such activity changes are governed by endogenous rhythms similar to those described for acid invertase (7).

The theoretical contribution of $\beta$-amylase toward sugar mobility has been discussed at length elsewhere [(6), pp. 220-221; (3)]. In essence this involves a rapid hydrolysis of immobile polyglucosides and reentry of the glucose residues into biosynthetic pathways for sucrose. In modern cane hybrids this activity is viewed as the breaking of a biochemical barrier against sugar synthesis and flow in the leaf, having little to do with massive starch accumulations known in earlier sugarcane varieties.

A potential role of ATPase in sugar movement relates to energy level regulation via phosphorylation reactions leading to ATP. Some authors suggest that ATPase is active in photophosphorylation processes in which the radiant energy of sunlight is converted to chemical energy or ATP [reviewed in an earlier paper (4)]. The nominally equal distribution of ATPase among mature leaf ranks and within the leaf blade (table 8 ) is an essential feature of the hypothetical vein-loading and transport systems which must continually expend energy $(23,25)$. Moreover, the lack of pronounced diurnal changes (fig. 2), or of any apparent relationship to chlorophyll content (fig. 1), is consonant with the view that sucrose transport and storage is mediated by a dark ATPase which resides in mitochondria rather than the chloroplast (5). 


\section{SUMMARY}

The distribution of sucrose, chlorophyll, $\beta$-amylase and ATPase was examined in sugarcane leaves of different rank sampled at different hours of the day. Leaf ranks -2 to +7 were detached at 0600,0800 , and 1330 hours and segmented into $30-\mathrm{cm}$ portions from base to apex prior to analysis. Positive basipetal sucrose gradients were found in all ranks with maxi-

TABlE 8.-ATPase activity in consecutive leaf segments, from base to apex, at different hours of the day ${ }^{1}$

\begin{tabular}{|c|c|c|c|c|c|c|c|}
\hline \multirow{2}{*}{ Leaf } & \multirow{2}{*}{ Hour } & \multicolumn{5}{|c|}{ Specific activity, at $\mathrm{cm}-$} & \multirow{2}{*}{ Mean } \\
\hline & & $0-30$ & $30-60$ & $60-90$ & $90-120$ & Apex & \\
\hline \multirow[t]{3}{*}{+1} & 0600 & 23.3 & 28.2 & 33.4 & 36.8 & 25.1 & 29.4 \\
\hline & 0800 & 28.9 & 30.1 & 39.7 & 38.6 & 32.3 & 33.9 \\
\hline & 1330 & 17.3 & 23.7 & 34.4 & 37.0 & 30.8 & 28.7 \\
\hline \multirow[t]{3}{*}{+3} & 0600 & 22.5 & 31.0 & 30.2 & 30.0 & 24.8 & 27.7 \\
\hline & 0800 & 18.8 & 20.2 & 27.5 & 32.7 & 27.7 & 25.4 \\
\hline & 1330 & 14.9 & 17.3 & 24.3 & 30.0 & 26.2 & 22.5 \\
\hline \multirow[t]{3}{*}{+5} & 0600 & 15.3 & 20.0 & 25.5 & 22.9 & 21.8 & 21.1 \\
\hline & 0800 & 14.9 & 19.8 & 20.0 & 20.8 & 27.1 & 20.5 \\
\hline & 1330 & 10.6 & 14.3 & 20.3 & 23.2 & 18.5 & 17.4 \\
\hline \multirow[t]{3}{*}{+6} & 0600 & 15.0 & 17.1 & 17.1 & 22.0 & 21.8 & 18.6 \\
\hline & 0800 & 15.5 & 15.9 & 22.9 & 23.3 & 27.2 & 21.0 \\
\hline & 1330 & 8.7 & 13.3 & 18.4 & 18.5 & 15.9 & 15.0 \\
\hline \multirow[t]{4}{*}{+7} & 0600 & 15.7 & 23.2 & 21.2 & 16.4 & 13.6 & 18.0 \\
\hline & 0800 & 15.9 & 18.1 & 20.8 & 19.6 & 23.4 & 19.6 \\
\hline & 1330 & 10.3 & 13.0 & 17.2 & 11.7 & 10.7 & 12.6 \\
\hline & Mean & 16.5 & 20.3 & 24.9 & 25.6 & 23.1 & \\
\hline
\end{tabular}

1 Midrib included.

Activity units per milligram of protein.

mum values at 1330 hours. Inverse gradients (acropetal) were obtained for chlorophyll, with large decreases between 0600 and 0800 hours in blade segments most exposed to light. $\beta$-amylase activity was inversely related to sucrose content between leaf ranks, and positively related from apex to base of individual blades. Pronounced increases occurred between 0600 and 0800 hours which appeared to be independent of changes in light intensity or chlorophyll content. Both $\beta$-amylase and ATPase were exceptionally active in the youngest leaf rank (-2), particularly in the darkened lower 
half. In mature leaves $(+1$ to +7$)$ ATPase activity was essentially constant relative to gradient, rank, and diurnal parameters. Important enzymic roles in foliar sucrose movement are suggested by the data. These are discussed in terms of polyglucoside hydrolysis and regulation of energy expenditure for sugar transport processes.

\section{RESUMEN}

Se estudió la distribución de la sacarosa, Ia clorofila, la $\beta$-amilasa y la ATP-asa en hojas de caña de azúcar de distintos niveles, de las cuales se tomaron muestras a diferentes horas del día. A las horas 0600,0800 y 1330 se desprendieron hojas de los niveles -2 hasta $+7 \mathrm{y}$, antes del análisis, se cortaron desde la base hasta el ápice en segmentos de $30 \mathrm{~cm}$. La sacarosa, de la cual se hallaron gradientes positivos basípetos en todos los niveles, alcanź́ valores máximos a las 1330 horas. Para la clorofila se obtuvieron gradientes inversos (acropetos), con grandes descensos entre las 0600 y las 0800 horas, en los segmentos que estuvieron expuestos a iluminación máxima. Entre los niveles de hojas la actividad de la $\beta$-amilasa guardó relación inversa con la sacarosa; en las láminas individuales la relación fue positiva del ápice a la base. Ocurrieron pronunciados aumentos entre las horas 0600 y 0800 y los mismos parecían ser independientes de los cambios en la intensidad de luz y en el contenido en saracosa. Tanto la $\beta$-amilasa como la ATP-asa estuvieron excepcionalmente activas en los niveles de hojas más jóvenes (-2), especialmente en la mitad inferior no expuesta a la luz. En hojas maduras $(+1$ a +7$)$ la actividad de la ATP-asa guardó una relación constante con los parámetros de gradiente, nivel y hora. Los datos señalan hacia importantes funcdiones enzímicas, las cuales se discuten en términos de la hidrólisis de los poliglucósidos y del consumo de la energía usada en la transportación del azúcar.

\section{LITERATURE CITED}

1. Alexander, A. G., Hydrolytic proteins of sugarcane. The acid phosphatases, J. Agr. Univ. P.R. 49: 204-08, 1965.

2. - Hydrolytic proteins of sugarcane. Amylase, J. Agr. Univ. P.R. 49: 308-24, 1965.

3. - The biosynthesis of starch in sugarcane, Proc. Int. Soc. Sugar Cane Technol 12: 625-38, 1967.

4. - Samuels, G., Spain, G. L., and Montalvo-Zapata, R., Physiology of sugarcane under water stress: Invertase, ATPase and amylase behavior in plants experiencing water deficiency, night flooding and continuous flooding, J. Agr. Univ. P.R. 56(2): 115-33, 1972.

5. - Montalvo-Zapata, R., and Kumar, A., Light- and nitrogen-sensitive ATPases in sugarcane leaves, Proc. Int. Soc. Sugar Cane Technol. 14: 673-78, 1972.

6. - Sugarcane Physiology, Elsevier Scientific Publishing Company, Amsterdam, 753 pp., 1973.

7. - Montalvo-Zapata, R., and Justiniano, M. G., Diurnal behavior of sugarcane acid invertase, J. Agr. Univ. P.R. 57(1): 84-6, 1973.

8. Arnon, D. I., Copper enzymes in isolated chloroplasts. Polyphenol oxidase in Bela vulgaris, Plant Physiol. 24: 1-15, 1949.

9. Beevers, H., Metabolic sinks. Chap. 8 in: Physiological Aspects of Crop Yields, J. D. Eastin (Ed.), Crop Science Society of America, Madison, Wisconsin, 1969.

10. Biddulph, O., Mechanisms of translocation of plant metabolites. Chap. 7 in: 
Physiological Aspects of Crop Yields, J. D. Eastin (Ed.) Crop Science Society of America, Madison, Wisconsin, 1969.

11. Canny, M. J., and Askham, M. J., Physiological inferences from the evidence of translocated tracer; a caution, Ann. Bot. (N.S.): 31 : 409-16, 1967.

12. Cardini, C. E., Leloir, L. F., and Chiriboga, J., The biosynthesis of sucrose, J. Biol. Chem. 214: 149-55, 1955.

13. Hartt, C. E., The fluctuations of sugars in the leaf blades of the sugarcane plant during the day and the night, Haw. Plant. Rec. 39: 298-326, 1936.

14. - Kortschak, H. P., Forbes, A. J., and Burr, G. O., Translocation of ${ }^{11} \mathrm{C}$ in sugarcane, Plant Physiol. 38: 305-18, 1963.

15. - -, and Kortschak, H. P., Tracing sugar in the cane plant, Proc. Int. Soc. Sugar Cane Technol. 11 : 323-34, 1963.

16. - Translocation of sugar in the cane plant, Haw. Sugar Technol. Ann. Rept., pp. 151-167, 1963.

17. - Translocation as a factor in photosynthesis, Naturwissenschaften 21: 66667, 1963.

18. - and Kortschak, H. P., Sugar gradients and translocation of sucrose in detached blades of sugarcane, Plant Physiol. 39 : 460-74, 1964.

19. - - - , and Burr, G. O., Effects of defoliation, deradication, and darkening the blade upon translocation of ${ }^{1} \mathrm{C}$ in sugarcane, Plant Physiol. 39: 15-22, 1964.

20. - Translocation in colored light, Plant Physiol. 41: 369-72, 1966.

21. —, and Kortschak, H. P., Radioactive isotopes in sugarcane physiology, Proc. Int. Soc. Sugarcane Technol. 12: 647-62, 1967.

22. Hatch, M. D., and Glasziou, K. T., Direct evidence for translocation of sucrose in sugarcane leaves and stems, Plant Physiol. 39: 180-4, 1964.

23. Kursanov, A. L., and Brovchenko, M. I., Effect of ATP on the entry of assimilates into the conducting system of sugar beets, Fiziol. Rastenii 8: 211-17 (English trans.), 1961.

24. - Metabolism and the transport of organic solutes, Adv. Bot. Res. 1: 209-78, 1963.

25. Shiroya, M., Comparison of upward and downward translocation of "C from a single leaf of sunflower, Plant Physiol. 43: 1,605-10, 1968.

26. Sutherland, E. W., Cori, C. F., Haynes, R., and Olsen, N. S., Purification of the hyperglycemic-glycogenolytic factor from insulin and from gastric mucosa, $\mathrm{J}$. Biol. Chem. 180: 825-37, 1949.

27. Van Dillewijn, C., Botany of Sugarcane, The Chronica Botanica Co., Waltham, Mass. pp. 213-15, 1952. 